\title{
RNA-seq Characterization of Melanoma Phenotype Switch in 3D Collagen after p38 MAPK Inhibitor Treatment
}

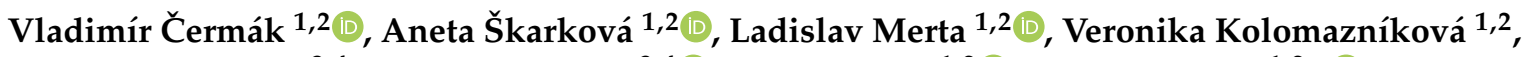 \\ Veronika Palušová ${ }^{3,4}$, Stjepan Uldrijan ${ }^{3,4}\left(\mathbb{D}\right.$, Daniel Rösel ${ }^{1,2}$ (D) and Jan Brábek 1,2,*(D) \\ 1 Department of Cell Biology, Charles University, Viničná 7, 12844 Prague, Czech Republic; \\ vladimir.cermak@natur.cuni.cz (V.Č.); aneta.skarkova@natur.cuni.cz (A.Š.); \\ ladislav.merta@natur.cuni.cz (L.M.); veronika.kolomaznikova@natur.cuni.cz (V.K.); \\ daniel.rosel@natur.cuni.cz (D.R.) \\ 2 Biotechnology and Biomedicine Centre of the Academy of Sciences and Charles University (BIOCEV), \\ Průmyslová 595, 25242 Vestec u Prahy, Czech Republic \\ 3 Department of Biology, Faculty of Medicine, Masaryk University, Kamenice 5, 62500 Brno, Czech Republic; \\ ver.palusova@mail.muni.cz (V.P.); uldrijan@med.muni.cz (S.U.) \\ 4 International Clinical Research Center, St. Anne's University Hospital, Pekařská 53, \\ 65691 Brno, Czech Republic \\ * Correspondence: jan.brabek@natur.cuni.cz; Tel./Fax: +420-3258-73900
}

Citation: Čermák, V.; Škarková, A.; Merta, L.; Kolomazníková, V.;

Palušová, V.; Uldrijan, S.; Rösel, D.; Brábek, J. RNA-seq Characterization of Melanoma Phenotype Switch in 3D Collagen after p38 MAPK Inhibitor Treatment. Biomolecules 2021, 11, 449. https://doi.org/10.3390/biom11030449

Academic Editor: Masaaki Oyama

Received: 27 January 2021

Accepted: 15 March 2021

Published: 17 March 2021

Publisher's Note: MDPI stays neutral with regard to jurisdictional claims in published maps and institutional affiliations.

Copyright: (c) 2021 by the authors. Licensee MDPI, Basel, Switzerland. This article is an open access article distributed under the terms and conditions of the Creative Commons Attribution (CC BY) license (https:// creativecommons.org/licenses/by/ $4.0 /)$.

\begin{abstract}
Melanoma phenotype plasticity underlies tumour dissemination and resistance to therapy, yet its regulation is incompletely understood. In vivo switching between a more differentiated, proliferative phenotype and a dedifferentiated, invasive phenotype is directed by the tumour microenvironment. We found that treatment of partially dedifferentiated, invasive A375M2 cells with two structurally unrelated p38 MAPK inhibitors, SB2021920 and BIRB796, induces a phenotype switch in 3D collagen, as documented by increased expression of melanocyte differentiation markers and a loss of invasive phenotype markers. The phenotype is accompanied by morphological change corresponding to amoeboid-mesenchymal transition. We performed RNA sequencing with an Illumina HiSeq platform to fully characterise transcriptome changes underlying the switch. Gene expression results obtained with RNA-seq were validated by comparing them with RT-qPCR. Transcriptomic data generated in the study will extend the present understanding of phenotype plasticity in melanoma and its contribution to invasion and metastasis.
\end{abstract}

Keywords: cancer; melanoma; metastasis; phenotype switch; amoeboid invasion

\section{Introduction}

Despite significant progress in therapy, melanoma remains a life-threatening disease with a high risk of early metastasis. Understanding the biological processes underlying melanoma metastasis is expected to generate new advances and therapeutic modalities in melanoma management [1]. Melanoma is a cancer arising from melanocytes, pigmentproducing cells located in the epidermis and a few other tissues. It shows unique biological features related to its developmental origin, namely specific differentiation plasticity and migratory behaviour. The central or master regulator of the melanocyte lineage is the transcription factor MITF [2,3]. MITF regulates expression of pigmentation-related genes, and coordinates differentiation and proliferation in developing melanocytes. In addition, it affects many other biological processes, including cell survival, invasion, senescence, metabolism, autophagy, lysosomal biogenesis, and DNA damage repair [2]. MITF is regulated at transcription and multiple post-transcriptional levels. Its transcription in the melanocyte lineage is driven by SOX10, WNT/ $\beta$-catenin and CREB, and is directly or indirectly suppressed by NF-kB, JNK, hedgehog, TGF $\beta$, activated RhoA, HIF1 $\alpha$, Brn2/POU3F2 and ATF4 [2-6]. 
A large-scale comparative study of published microarray data from melanoma cell lines identified two distinct gene expression profiles and associated phenotypes that were termed "invasive" and "proliferative" [7]. The different gene expression patterns correspond to low and high MITF activity and the related differentiation status of the cells. The dedifferentiated, invasive phenotype was originally characterised by a sustained activation of TGF $\beta$ target genes, a shift from canonical to non-canonical WNT signalling, and a low expression of MITF-regulated genes. Later, it was found that it also involves sustained NF-kB, Yap/Taz-TEAD, ER-stress and Rho-ROCK signalling [5,7-11]. Melanoma dedifferentiation and invasive phenotype can be induced or enhanced by inflammatory factors (IL1, TNF $\alpha$ ), TGF $\beta$, glutamine starvation, conditions of low adhesion (e.g., growth in melanospheres) and hypoxia [5,12-18]. It is associated with resistance to both BRAF inhibitors and immunotherapy, as well as with enhanced metastasis and poor prognosis $[10,17-21]$. The underlying signalling pathways, their cross-talks and feed-forward loops responsible for, or, presumably, contributing to, the preservation of the invasive phenotype in melanoma cells and examples of transcripts specifically associated with either phenotype, are summarised in Figure 1 [8,11,22-35].

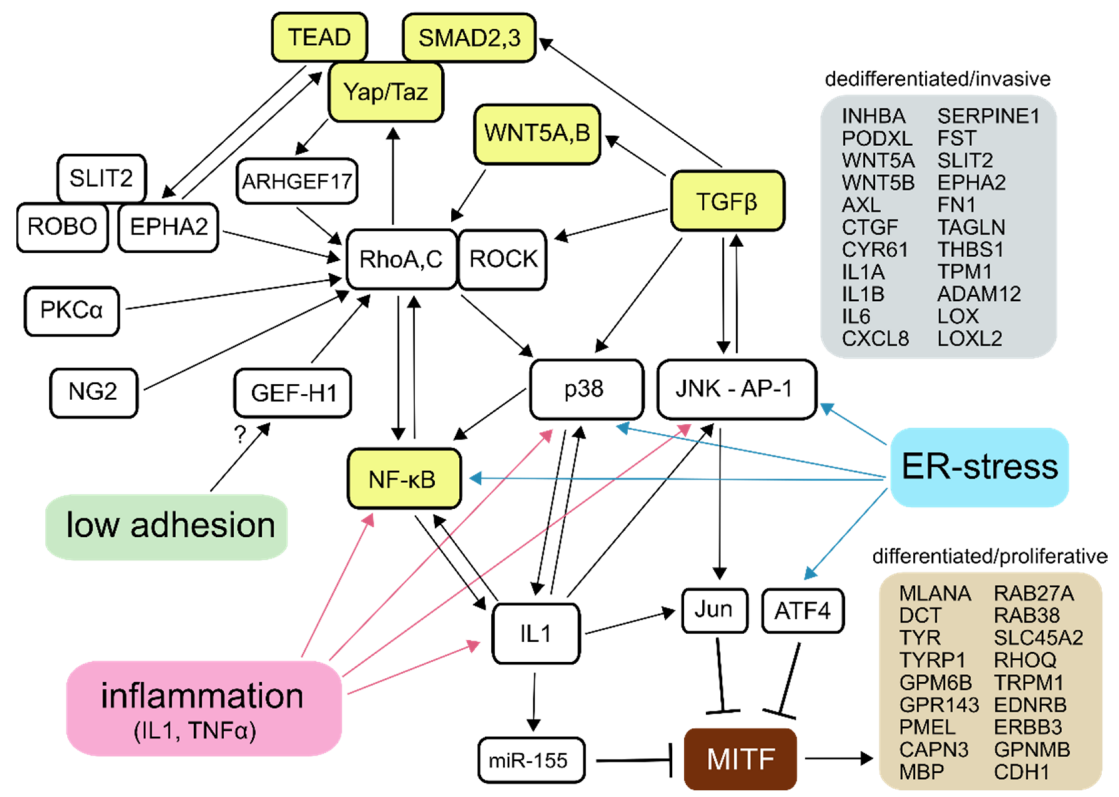

Figure 1. Signalling circuitry of the invasive melanoma phenotype. Essential, broadly accepted regulators are marked by yellow colour. Other regulators, relationships and responses to stimuli were compiled from the literature related to both invasive-proliferative phenotype plasticity and amoeboid invasion. Listed examples of genes whose high expression is characteristic of either phenotype were assembled from the published literature and datasets.

Cancer cells, including melanoma, can individually invade a 3D environment in either a mesenchymal mode, which depends on integrin-mediated adhesion and extracellular protease activity, or in an amoeboid mode that is independent of integrins and localised proteolysis, and is also characterised by largely dissociated microtubules and high RhoAROCK-dependent contractility [36-38]. As RhoA-ROCK signalling is also required for mesenchymal invasion, it is an attractive target for antimetastatic therapy [39,40]. A375M2 metastatic melanoma cells have been a popular model for studying amoeboid invasion and its regulation, for they show prominent blebbing amoeboid morphology in, or on top of, soft collagen matrices, good long-term viability under such conditions, and, importantly, display substantial plasticity in terms of induced migratory phenotype transitions between amoeboid and mesenchymal modes, referred to as invasion plasticity. So far, amoeboid-mesenchymal transition (AMT) in A375M2 has been achieved by chemical inhibition of ROCK kinases, or gene targeting or knockdowns of miscellaneous regula- 
tors involved in the underlying signalling network [29,30,41-45]. Here, we show, for the first time, that treatment of A375M2 cells embedded in a 3D collagen matrix with compounds SB202190 and BIRB796 induces a phenotype switch, as documented by decreased expression of dedifferentiated/invasive phenotype-associated genes and upregulation of differentiated/proliferative phenotype-associated genes. The differentiation phenotype switch is accompanied by a morphological shift from a rounded to an elongated shape, which is indicative of AMT, suggesting that melanoma phenotype plasticity might be interconnected with invasion plasticity. SB202190 is more potent than BIRB796 in all observed effects, particularly in the induction of differentiation-related markers. While both compounds have been developed and used as p38 MAPK inhibitors, they can significantly inhibit several p38-unrelated kinases (see Table 1) [46,47]. Some of these kinases may affect melanoma cell phenotype, as exemplified by SB202190-specific inhibition of BRAF [48]. Recently, an important property distinguishing SB202190 from BIRB796 was identified: a SB202190-specific, p38-independent ability to robustly translocate lysosomal membranebound TFEB, a MITF-related protein, to the nucleus of melanoma cells [48]. The same effect was observed for TFEB and TFE3 (another MITF family member) in non-melanoma cells [49]. We confirmed that SB202190, but not BIRB796, elicits nuclear translocation of the MITF-A isoform in melanoma cells (see Figshare file, "Subcellular localisation of MITF" [50]). While MITF-M, the major isoform in melanoma/melanocytes, is constitutively localised in the nucleus, the localisation is not regulated by mTORC1, unlike the other MITF isoforms and TFEB, and does not change after SB202190 or BIRB796 treatment; it forms heterodimers with the other isoforms and with TFEB, TFEC and TFE3 [51,52]. Massive nuclear translocation of these proteins due to SB202190 treatment thus might potentiate transactivation by MITF-M or replace it in the transactivating complexes. Indeed, MITF-A was found to be a more potent activator of DCT than MITF-M, and TFE3 may replace MITF-M in the complex with LEF-1 to activate the DCT promoter $[53,54]$.

Table 1. Targets and off-targets of SB202190 and BIRB796. Plus signs mark $\mathrm{K}_{\mathrm{d}} \mathrm{nM}$ values from ref. 46: $+<1000,++<100,+++<10,++++<1$. Crosses mark residual kinase activity in the presence of $1 \mu \mathrm{M}$ inhibitor (from ref. $47, \mathrm{x}<50 \%, \mathrm{xx}<10 \%$ ).

\begin{tabular}{|c|c|c|}
\hline Kinase & SB202190 & BIRB796 \\
\hline p38alpha & $x x /+++$ & $x x /++++$ \\
\hline p38beta & $x x /++$ & $\mathrm{x} /$ \\
\hline p38gamma & & $x /+$ \\
\hline p38delta & & $\mathrm{x}$ \\
\hline JNK2 & $x /+$ & $x x /++$ \\
\hline JNK3 & $x /++$ & \\
\hline NLK & $x /++$ & \\
\hline RIPK2/RIP2 & $\mathrm{xx} /+$ & \\
\hline GAK & $x x /++$ & \\
\hline CK1delta & $x /++$ & \\
\hline BRAF & + & \\
\hline GSK3beta & $x$ & \\
\hline CK1epsilon & + & \\
\hline Lck & $x$ & \\
\hline ACVR1B & + & \\
\hline CIT & + & \\
\hline CDC42BPG & + & \\
\hline EGFR & + & \\
\hline PRKACB & + & \\
\hline RPS6KA1 & + & \\
\hline RPS6KA6 & + & \\
\hline STK36 & + & \\
\hline DDR1 & & ++ \\
\hline TIE1 & & ++ \\
\hline MAP4K4 & & + \\
\hline STK10 & & + \\
\hline SLK & & + \\
\hline ABL1 & & + \\
\hline DDR2 & & + \\
\hline TIE2 & & + \\
\hline RSK1 & & $\mathrm{x}$ \\
\hline RSK2 & & $\mathrm{x}$ \\
\hline BRSK2 & & $\mathrm{x}$ \\
\hline
\end{tabular}




\section{Materials and Methods}

\subsection{Cells Culture, Treatments and Morphological Analysis}

A375M2 cells were maintained in DMEM (4.5 g/L glucose, pyruvate) supplemented with $10 \%$ foetal bovine serum and $50 \mu \mathrm{g} / \mathrm{mL}$ gentamicin (all from Sigma-Aldrich, St. Louis, $\mathrm{MO}, \mathrm{USA}$ ) at $37^{\circ} \mathrm{C}$ in a humidified atmosphere with $5 \% \mathrm{CO}_{2}$. The cultures were regularly tested for mycoplasma contamination. 3D cell culture experiments were performed with rat tail collagen (SERVA, Heidelberg, Germany) at a concentration of $1 \mathrm{mg} / \mathrm{mL}$ and DMEM supplemented with $1 \%$ foetal bovine serum, $15 \mathrm{mM}$ HEPES and $50 \mu \mathrm{g} / \mathrm{mL}$ gentamicin. In all experiments, cells were treated with $10 \mu \mathrm{M}$ SB202190 (Santa Cruz Biotechnology, Santa Cruz, CA, USA), $10 \mu \mathrm{M}$ BIRB796 alias doramapimod (LC Laboratories), or an equivalent volume of DMSO only ( $0.1 \%$ final concentration). To quantify cell morphology in the 3D collagen matrix, 100,000 cells were seeded in $250 \mu \mathrm{L}$ of collagen in a 48 -well plate. Hoffman modulation contrast microscopy images were taken $48 \mathrm{~h}$ later from approx. 20 planes along the z-axis. Cells were classified as elongated or rounded as described previously [55]. Please note that different A375-derived cell lines with almost identical names (A375M2, A375 M-2, A375M, etc.) were created in similar ways in a few completely independent studies [56,57]. A375M2 cells used in this study are those from Clark et al., and were kindly provided by Prof. Richard Hynes.

\subsection{RNA Extraction and Sequencing}

A total of 330,000 A375M2 cells were cultured in $500 \mu \mathrm{L}$ of 3D collagen gel for $48 \mathrm{~h}$ in a 24-well plate. RNA was isolated as described in detail previously [55]. Polyadenylated RNA was enriched with Oligo d $(\mathrm{T})_{25}$ Magnetic Beads (New England Biolabs, Ipswich, MA, USA), according to the manufacturer's instructions. A stranded, Illumina HiSeqcompatible library was constructed with a ScriptSeq Complete (Human/Mouse/Rat) library preparation kit (Epicentre), according to the manufacturer's instructions. The quality and size distribution of sequencing libraries was verified with P5-P7 PCR, and the concentrations were determined using a PicoGreen (Thermo Fisher Scientific, Waltham, MA, USA) fluorescence measurement. An equimolar pool of 12 sample libraries was sequenced on one whole lane of an Illumina HiSeq 2000/2500 series sequencer in high output, paired mode $(2 \times 125$ cycles). Raw reads were trimmed from adapter sequences with Cutadapt [58] (version 1.15), quality checked with FastQC, and mapped to human genome version GRCh38.100 with the STAR short read aligner [59] version 2.7.4a, with default settings and output extended with read counts per gene. Complete adaptertrimmed fastq data are available from the ArrayExpress database at EMBL-EBI under accession number E-MTAB-9273 [60].

\subsection{Reverse Transcription-Quantitative Polymerase Chain Reaction (RT-qPCR)}

All the RT-qPCR experiments were performed according to MIQE guidelines [61]. Briefly, total RNA was extracted from cells embedded in 3D collagen matrix as described above. RNA reverse transcription was performed using M-MuLV Reverse Transcriptase (NEB) with $1 \mu \mathrm{M}$ oligo(dT) and $(\mathrm{dN})_{15}$ primer and $1.5 \mu \mathrm{g}$ of total RNA. SYBR green-based qPCR was performed in a LightCycler 480 Instrument (Roche). For primer details, see the file, PCR.primers.xlsx, available from Figshare [50]. Cq and relative expression values were calculated in $\mathrm{R}$ with ReadqPCR and NormqPCR packages, using TARDBP and THRAP3 as reference gene indices (selected based on geNORM analysis) [62,63]. Significance of differences was analysed with two-way ANOVA and pairwise paired $t$-tests, with $p$-value adjustment for multiple testing (Benjamini-Hochberg [64]).

\subsection{Statistical Analysis}

To estimate differential gene expression from RNA sequencing data, a workflow based on the STAR aligner and DESeq2 R package was used, as described previously [65]. We used rlog-transformed values for principal component analysis. Gene set enrichment analysis was performed with Enrichr [66]. We utilised core R functions to compare data 
produced in this work against two public datasets (Verfaillie et al. 2015 and Folberg et al. 2006) $[11,67]$. We calculated the numbers of shared genes (represented by gene symbols) for all possible pairs of gene sets, and the related Jaccard indices and hypergeometric right-tail cumulative $p$-values, to estimate the statistical significance of the intersections. As an approximation, we used the total number of all HGNC gene symbols assigned to protein-coding and non-coding RNA genes $(27,371)$ as the size of the source population in hypergeometric tests. Venn diagrams representing intersections of the gene sets were generated using a Multiple List Comparator online tool [68].

\section{Results}

3.1. SB202190 and BIRB796 Induce a Phenotype Switch in A375M2 Cells Cultured in 3D Collagen

Treatment of A375M2 melanoma cells with $10 \mu \mathrm{M}$ compounds SB202190 and BIRB796 for $48 \mathrm{~h}$ in 3D collagen resulted in an elongated shape in the majority of the cell population (Figure 2A,C), also see Figshare item, "Bright field microscopy photographs of A375M2 3D cell cultures"). The compounds were well tolerated, with only a mild decline in cell numbers after SB202190 treatment (Figure 2B). RT-qPCR analysis of transcripts associated with the dedifferentiated/invasive phenotype (INHBA, PODXL, IL1A, IL1B), and of MITFregulated genes (DCT, MLANA) associated with the differentiated/proliferative phenotype, confirmed a phenotype switch consistent with the characteristic gene expression signature described in the literature (Figure 2D). SB202190 was more potent than BIRB796 in both morphological and gene expression level effects.

A

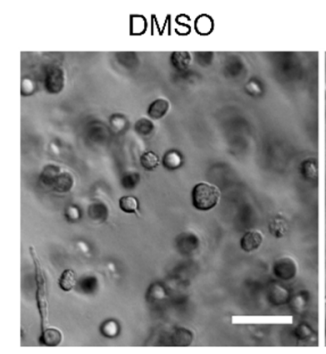

C

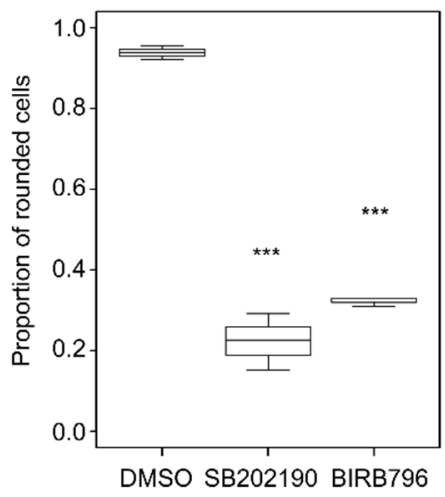

SB202190

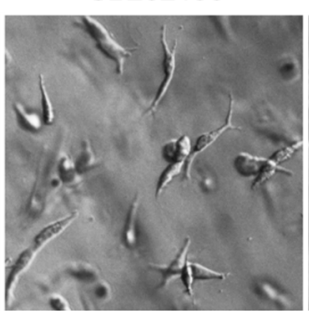

$\mathrm{D}$

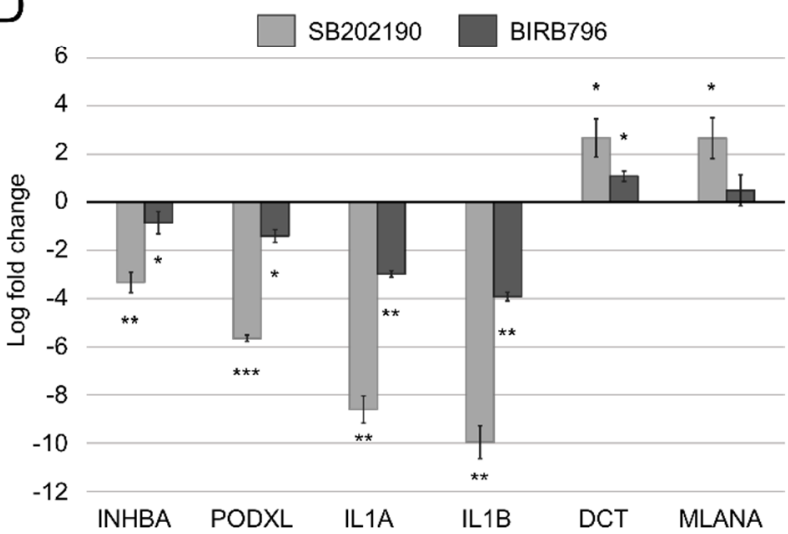

Figure 2. Phenotype switch induced by SB202190 and BIRB796 in A375M2 cultured in 3D collagen. (A) Representative wide-field images of cells in 3D collagen treated with DMSO, SB202190 or BIRB796. Scale bar: $75 \mu$ m. (B) Numbers of live cells after $48 \mathrm{~h}$ of the indicated treatments counted in equal volumes of 3D gels and normalised to DMSO controls (SB-SB202190, BIRB-BIRB796). Averages of three independent biological replicates; error bars: standard deviation. (C) Quantification of cell morphology in 3D collagen (three biological replicates, logistic regression with Wald test). (D) RT-qPCR detection of changes in expression of the indicated genes. Averages of three independent biological replicates; error bars: standard deviation. $p$-values: ${ }^{* *} p<0.001,{ }^{* *} p<0.01,{ }^{*} p<0.05$. 


\subsection{Transcriptomic Profiling of the Phenotype Switch-Associated Changes with RNA-seq}

To uncover the transcriptomic changes underlying the dual phenotype switch, we performed RNA sequencing of mRNA samples from SB202190, BIRB796 or DMSO-treated cells prepared in four independent biological replicates. The cells were kept for $48 \mathrm{~h}$ in $3 \mathrm{D}$ collagen with the compounds, and then the whole samples, including the collagen, were homogenised and further processed for RNA sequencing. Polyadenylated RNA was enriched with oligo-dT magnetic beads, converted into a stranded cDNA library, and sequenced with an Illumina HiSeq sequencer (Figure 3).

\section{A375m2 melanoma cells - phenotype switch in 3D collagen}

3D cell culture

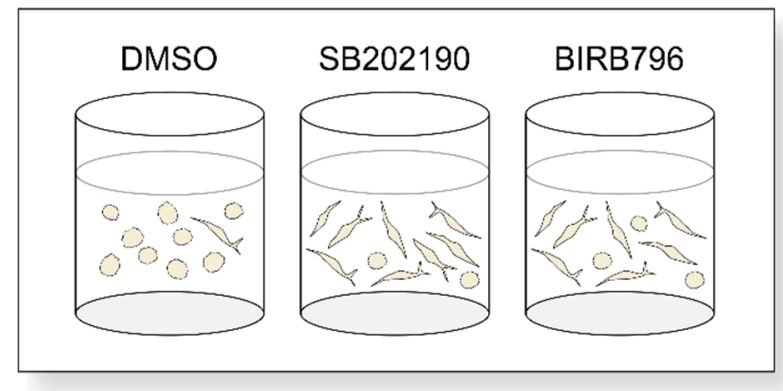

Sample processing

$$
\begin{aligned}
& \text { mRNA isolation } \\
& \text { Library construction } \\
& \text { Quality check and pooling }
\end{aligned}
$$

\section{Data acquisition}

Library sequencing on

Illumina HiSeq

\section{Data processing}

\section{Read processing: Cutadapt \\ Read mapping: STAR \\ Normalisation \& differential \\ gene expression: DESeq2}

Figure 3. Data acquisition and processing strategy.

The sequencing yielded approx. 21-26.5 million paired-end reads per sample. Raw reads trimmed from adapter sequences were quality checked with FastQC software [69]. FastQC's plots of Phred scores by position showed typical profiles with decreasing quality towards the ends of reads (Figure 4A). 
A

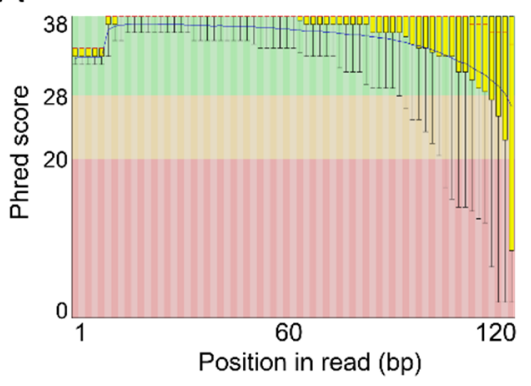

C

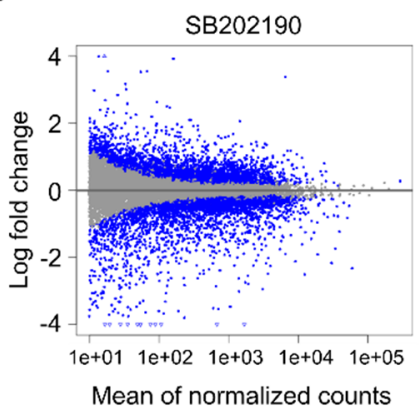

B

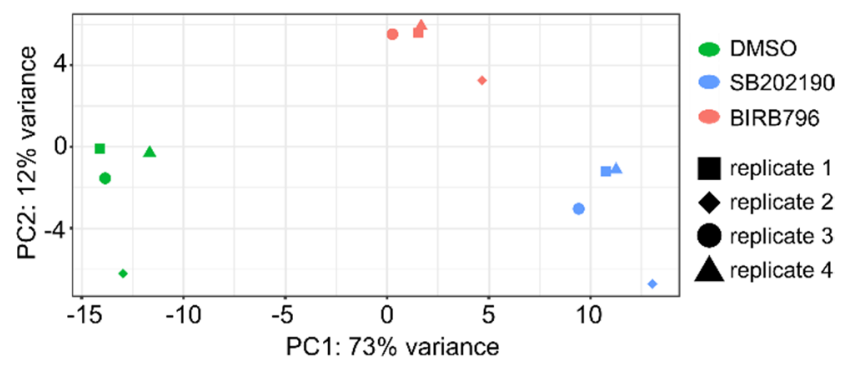

D
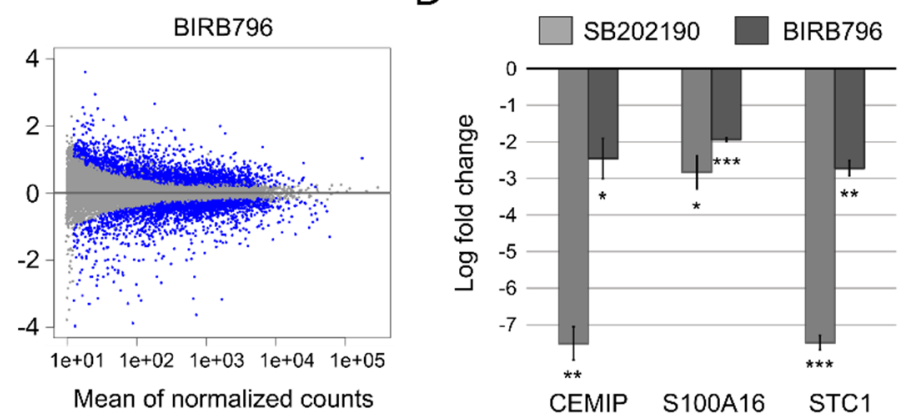

$E$

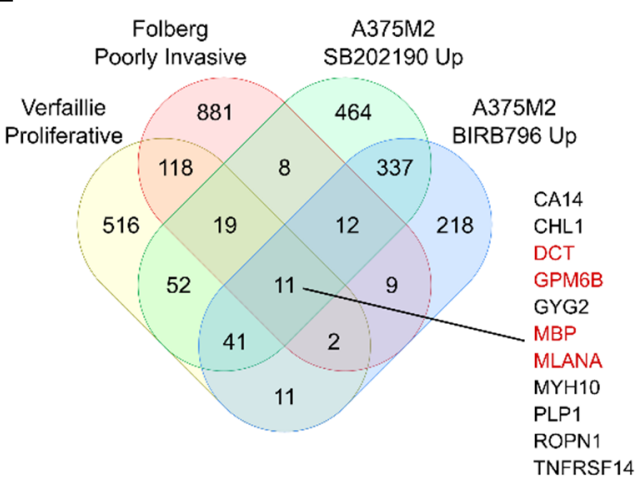

F

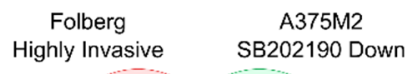

\begin{tabular}{l|ccc}
$\begin{array}{l}\text { Verfaillie } \\
\text { Invasive }\end{array}$ & 1034 & 593 & $\begin{array}{c}\text { A375M2 } \\
\text { BIRB796 Down }\end{array}$
\end{tabular}

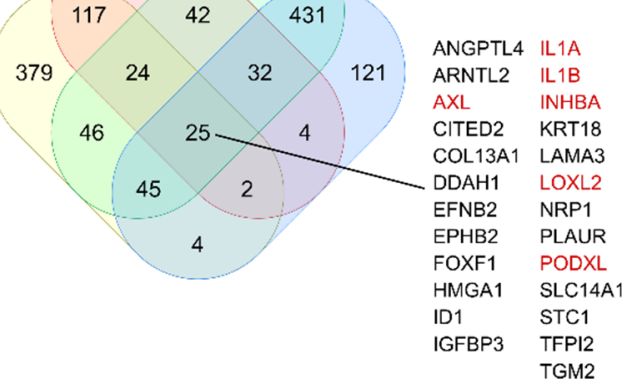

Figure 4. Technical validation of RNA sequencing results. (A) Per base sequence quality of RNA sequencing reads expressed as Phred score by position, sample 1, first reads. (B) Principal component analysis of gene expression profiles. (C) MA plot of $\log 2$ fold change values against normalised counts for each gene in the analysis. Blue points mark genes with FDR $<0.1$. (D) Log2 fold change values of the indicated genes detected by RT-qPCR in three samples independent from the RNA-seq series. Error bars: standard deviation. Adjusted $p$-values: ${ }^{* * *} p<0.001,{ }^{* *} p<0.01,{ }^{*} p<0.05$. (E,F) Venn diagrams representing intersections of gene lists from the indicated datasets. Highlighted in red are the genes whose higher expression is well known to be characteristic of either the differentiated/proliferative (E) or of the dedifferentiated/invasive phenotype (F).

The mapping metrics of the STAR aligner showed an average paired read length of 240 nucleotides. On average, the aligner uniquely mapped $93.6 \%$ of the fragments to the human genome; $3.1 \%$ of the fragments were multi-mapped and $3.1 \%$ of the fragments were excluded for being too short. For the complete mapping metrics, see Figshare file, "RNA sequencing raw data and mapping metrics" [50]. Principal component analysis of normalised gene expression profiles showed that the treatments were the dominant source of variation (Figure 4B). Differential gene expression analysis with DESeq2 [70] identified that 2700 out of 16,612 Ensembl genes $(16.3 \%)$ changed with adjusted $p$-value $<0.1$ and fold change $>1.5$ after treatment with SB202190. BIRB796 treatment changed the expression of 1638 out of $16,612(9.9 \%)$ genes. The distribution of affected transcripts by gene expression 
level is depicted as an MA plot in Figure 4C. Complete results are available from Figshare ("Differential gene expression analysis") [50]. Selected differentially expressed genes from the gene lists, characteristic of either invasive or proliferative phenotypes (see Figure 1), are listed in Table 2.

Table 2. Changes in expression of melanoma phenotype-related genes detected with RNA-seq. Average $\log 2$ fold change values \pm standard error as obtained with DESeq2.

\begin{tabular}{ccc}
\hline Gene & SB202190 & BIRB796 \\
\hline TRPM1 & $4.00 \pm 0.67$ & \\
DCT & $3.38 \pm 0.09$ & $1.37 \pm 0.09$ \\
MLANA & $2.47 \pm 0.18$ & $0.94 \pm 0.19$ \\
GPM6B & $2.07 \pm 0.08$ & $1.00 \pm 0.08$ \\
PMEL & $1.58 \pm 0.27$ & \\
TYR & $1.39 \pm 0.08$ & \\
MBP & $1.17 \pm 0.34$ & $1.52 \pm 0.34$ \\
RAB27A & $0.95 \pm 0.11$ & \\
CAPN3 & $0.88 \pm 0.13$ & \\
GPNMB & $0.80 \pm 0.07$ & $-3.06 \pm 0.29$ \\
IL1B & $-4.48 \pm 0.33$ & $-1.95 \pm 0.15$ \\
IL1A & $-3.80 \pm 0.18$ & $-2.01 \pm 0.15$ \\
CXCL8 & $-3.60 \pm 0.18$ & \\
SERPINE1 & $-3.07 \pm 0.58$ & $-1.36 \pm 0.15$ \\
PODXL & $-2.83 \pm 0.16$ & $-1.11 \pm 0.34$ \\
AXL & $-2.70 \pm 0.41$ & $-0.88 \pm 0.12$ \\
INHBA & $-2.24 \pm 0.12$ & $-1.23 \pm 0.09$ \\
FN1 & $-1.91 \pm 0.09$ & $-0.78 \pm 0.10$ \\
LOXL2 & $-1.81 \pm 0.10$ & $-1.13 \pm 0.11$ \\
FST & $-1.61 \pm 0.11$ & $-0.60 \pm 0.10$ \\
ADAM12 & $-1.34 \pm 0.10$ & \\
WNT5B & $-0.82 \pm 0.35$ & \\
WNT5A & $-0.80 \pm 0.11$ & \\
THBS1 & $-0.73 \pm 0.11$ & \\
\hline & & \\
& &
\end{tabular}

Next, we analysed the differentially expressed genes for over-representation of gene lists from published datasets using the Enrichr web server (Table 3). We found that the genes upregulated by SB202190 and BIRB796 are significantly enriched with genes with high expression in a subset of melanoma cell lines from the NCI-60 cancer cell line panel. Importantly, all the cell lines in this subset were previously classified as "proliferative" within a large panel of melanoma cell lines, see the HOPP database [71]. The genes downregulated by the compounds showed many more concordant enrichments; Table 3 displays the top enriched GO Biological Process terms and TRRUST transcriptional regulatory networks [72]. For complete results, see the Figshare file, "Gene set enrichments".

Table 3. Gene set enrichment analysis. Over-representation of gene lists from published datasets, in the differentially expressed genes detected in this study, was analysed using the Enrichr web server. Adjusted $p$-values.

\begin{tabular}{llcc}
\hline \multicolumn{1}{c}{ Database } & \multicolumn{1}{c}{ Data } & SB202190 & BIRB796 \\
\hline & UACC257 & $1.83 \times 10^{-10}$ & $1.33 \times 10^{-4}$ \\
NCI-60 cancer cell line panel vs. & SKMEL5 & $1.83 \times 10^{-10}$ & $7.06 \times 10^{-2}$ \\
upregulated genes & SKMEL28 & $1.46 \times 10^{-6}$ & $2.49 \times 10^{-3}$ \\
& MALME 3M & $4.46 \times 10^{-5}$ & $1.85 \times 10^{-2}$ \\
& M14 & $5.64 \times 10^{-3}$ & $1.07 \times 10^{-1}$ \\
\hline
\end{tabular}


Table 3. Cont.

\begin{tabular}{|c|c|c|c|}
\hline Database & Data & SB202190 & BIRB796 \\
\hline \multirow{12}{*}{$\begin{array}{l}\text { GO-Biological Process vs. } \\
\text { downregulated genes }\end{array}$} & extracellular matrix & $3.44 \times 10^{-20}$ & $2.27 \times 10^{-11}$ \\
\hline & $\begin{array}{l}\text { regulation of cell proliferation } \\
\text { (GO:0042127) }\end{array}$ & $2.79 \times 10^{-11}$ & $2.09 \times 10^{-5}$ \\
\hline & $\begin{array}{l}\text { regulation of apoptotic process } \\
\text { (GO:0042981) }\end{array}$ & $4.35 \times 10^{-11}$ & $1.38 \times 10^{-9}$ \\
\hline & $\begin{array}{l}\text { regulation of cell migration } \\
\text { (GO:0030334) }\end{array}$ & $6.14 \times 10^{-11}$ & $4.86 \times 10^{-7}$ \\
\hline & $\begin{array}{l}\text { regulation of angiogenesis } \\
\text { (GO:0045765) }\end{array}$ & $8.39 \times 10^{-9}$ & $3.34 \times 10^{-5}$ \\
\hline & $\begin{array}{l}\text { negative regulation of } \\
\text { programmed cell death } \\
\text { (GO:0043069) }\end{array}$ & $9.99 \times 10^{-9}$ & $3.34 \times 10^{-5}$ \\
\hline & $\begin{array}{l}\text { cellular response to cytokine } \\
\text { stimulus (GO:0071345) }\end{array}$ & $1.86 \times 10^{-8}$ & $2.11 \times 10^{-4}$ \\
\hline & $\begin{array}{l}\text { positive regulation of } \\
\text { angiogenesis (GO:0045766) }\end{array}$ & $3.98 \times 10^{-8}$ & $6.02 \times 10^{-5}$ \\
\hline & $\begin{array}{l}\text { regulation of signal } \\
\text { transduction (GO:0009966) }\end{array}$ & $3.98 \times 10^{-8}$ & $6.02 \times 10^{-5}$ \\
\hline & $\begin{array}{l}\text { negative regulation of } \\
\text { apoptotic process (GO:0043066) }\end{array}$ & $7.51 \times 10^{-8}$ & $2.06 \times 10^{-5}$ \\
\hline & $\begin{array}{l}\text { positive regulation of cell } \\
\text { migration (GO:0030335) }\end{array}$ & $7.51 \times 10^{-8}$ & $7.08 \times 10^{-5}$ \\
\hline & $\begin{array}{l}\text { regulation of MAPK cascade } \\
\text { (GO:0043408) }\end{array}$ & $2.39 \times 10^{-7}$ & $6.17 \times 10^{-5}$ \\
\hline \multirow{8}{*}{$\begin{array}{l}\text { TRRUST vs. downregulated } \\
\text { genes }\end{array}$} & NFKB1 human & $8.76 \times 10^{-9}$ & $1.85 \times 10^{-6}$ \\
\hline & RELA human & $3.55 \times 10^{-8}$ & $1.08 \times 10^{-5}$ \\
\hline & NFKB1 mouse & $7.76 \times 10^{-8}$ & $1.01 \times 10^{-11}$ \\
\hline & VHL human & $5.70 \times 10^{-7}$ & $5.01 \times 10^{-4}$ \\
\hline & STAT3 mouse & $7.85 \times 10^{-7}$ & $1.08 \times 10^{-5}$ \\
\hline & SP1 mouse & $8.33 \times 10^{-7}$ & $1.07 \times 10^{-11}$ \\
\hline & EGR1 mouse & $2.54 \times 10^{-6}$ & $3.75 \times 10^{-6}$ \\
\hline & ETS1 human & $2.72 \times 10^{-6}$ & $4.92 \times 10^{-5}$ \\
\hline
\end{tabular}

\subsection{Validation and Reproducibility of the RNA-seq Results}

To validate the biological reproducibility of the results of differential gene expression analysis, we performed RT-qPCR measurements of three selected transcripts-CEMIP, S100A16 and STC1-in RNA samples independent from those used for the RNA sequencing (three biological replicates). The corresponding genes were identified as significantly differentially expressed in both SB202190 and BIRB796 data, and are also present in published gene expression signatures of the invasive phenotype, e.g., S100A16 in Verfaillie et al. 2015, Tirosh et al. 2016 and Jeffs et al. 2009 [11,73,74]. The results confirmed that the genes were similarly affected in the independent samples (Figure 4D). We also wondered to what extent are the data generated in the presented study matching the published gene expression signatures characterising the phenotype switch. For comparison, we chose two published gene expression profiles of invasive and proliferative phenotypes with a total number of affected genes similar to our study-Verfaillie et al. 2015 and Folberg et al. $2006[11,67]$. The comparison revealed that the two published studies overlap, with the data from SB202190-treated A375M2 cells being similar. Data from BIRB796-treated cells overlap by approx. half of the numbers, but still significantly (see Figshare data, "Comparison of A375M2 data sets against public datasets" [50]). We also analysed all intersections of the gene lists in detail and found subsets shared by all the lists (11 genes for "proliferative" and 25 genes for "invasive" sets) containing known markers of the respective phenotypes (Figure 4E,F).

\section{Discussion}

The signalling network controlling amoeboid phenotype in melanoma, as has been previously uncovered in A375M2 cells, is virtually identical to the one responsible for the dedifferentiated/invasive phenotype (i.e., NF-kB, TGF $\beta$ and non-canonical WNT 
signalling) $[41,42,75]$. The amoeboid phenotype is also known to be suppressed by $\beta$ catenin-stimulated MITF expression [76]. EPHA2, which is highly expressed in dedifferentiated/invasive melanoma cells, stimulates RhoA activity and promotes amoeboid migration [77]. It thus seems that amoeboid invasion is a manifestation of the dedifferentiated/invasive phenotype observable under suitable 3D conditions (in terms of cell viability and matrix composition). Our data bring essential additional support for such a hypothesis and encourage further large-scale 3D culture-based or intravital analyses required for definitive confirmation. We suggest that the presented data are of high relevance to melanoma biology and cancer metastasis research fields, as they bridge invasion and phenotype plasticity in melanoma cells.

Author Contributions: Conceptualization, V.Č., J.B., and. D.R.; methodology, V.Č.; software, V.Č.; validation, V.Č., A.Š. and L.M.; formal analysis, V.Č.; investigation, V.Č., A.S.., L.M., V.K. and V.P.; data curation, V.Č.; writing—original draft preparation, V.Č.; writing—review and editing, V.Č., A.̌̌s., J.B., D.R. and S.U.; visualization, V.C..; supervision, J.B., D.R. and S.U.; funding acquisition, J.B. and D.R. All authors have read and agreed to the published version of the manuscript.

Funding: This research was funded by the Kellner Family Foundation Principal Investigator Grant, Centre for Tumour Ecology (reg. no. CZ.02.1.01/0.0/0.0/16_019/0000785) supported by the Operational Programme Research, Development and Education, and by the Ministry of Education, Youth and Sports of CR within the LQ1604 National Sustainability Program II (Project BIOCEV-FAR).

Data Availability Statement: Supporting data referenced in the text, complete results of differential gene expression analysis, and published data comparisons have been deposited in the Figshare repository [50]. Adapter-trimmed RNA sequencing data have been deposited in the ArrayExpress database at EMBL-EBI (accession number E-MTAB-9273) [60]. The scripts used in data processing are available from Figshare [50] (see "Code used in data processing").

Acknowledgments: pEGFP-N1-MITF-A was a gift from Shawn Ferguson (Addgene plasmid \#38132).

Conflicts of Interest: The authors declare no conflict of interest.

\section{References}

1. Rambow, F.; Marine, J.-C.; Goding, C.R. Melanoma plasticity and phenotypic diversity: Therapeutic barriers and opportunities. Genes Dev. 2019, 33, 1295-1318. [CrossRef]

2. Goding, C.R.; Arnheiter, H. Mitf—-the First 25 Years. Genes Dev. 2019, 33, 983-1007. [CrossRef] [PubMed]

3. Hartman, M.L.; Czyz, M. MITF in melanoma: Mechanisms behind its expression and activity. Cell. Mol. Life Sci. 2015, 72, 1249-1260. [CrossRef]

4. Kim, J.-H.; Hong, A.-R.; Kim, Y.-H.; Yoo, H.; Kang, S.-W.; Chang, S.E.; Song, Y. JNK suppresses melanogenesis by interfering with CREB-regulated transcription coactivator 3-dependent MITF expression. Theranostics 2020, 10, 4017-4029. [CrossRef]

5. Falletta, P.; Sanchez-Del-Campo, L.; Chauhan, J.; Effern, M.; Kenyon, A.; Kershaw, C.J.; Siddaway, R.; Lisle, R.J.; Freter, R.; Daniels, M.J.; et al. Translation reprogramming is an evolutionarily conserved driver of phenotypic plasticity and therapeutic resistance in melanoma. Genes Dev. 2017, 31, 18-33. [CrossRef]

6. Buscà, R.; Bertolotto, C.; Abbe, P.; Englaro, W.; Ishizaki, T.; Narumiya, S.; Boquet, P.; Ortonne, J.P.; Ballotti, R. Inhibition of rho is required for CAMP-induced melanoma cell differentiation. Mol. Biol. Cell 1998, 9, 1367-1378. [CrossRef]

7. Hoek, K.S.; Schlegel, N.C.; Brafford, P.; Sucker, A.; Ugurel, S.; Kumar, R.; Weber, B.L.; Nathanson, K.L.; Phillips, D.J.; Herlyn, M.; et al. Metastatic potential of melanomas defined by specific gene expression profiles with no BRAF signature. Pigment. Cell Res. 2006, 19, 290-302. [CrossRef]

8. Vivas-García, Y.; Falletta, P.; Liebing, J.; Louphrasitthiphol, P.; Feng, Y.; Chauhan, J.; Scott, D.A.; Glodde, N.; Chocarro-Calvo, A.; Bonham, S.; et al. Lineage-restricted regulation of SCD and fatty acid saturation by MITF controls melanoma phenotypic plasticity. Mol. Cell 2020, 77, 120-137.e9. [CrossRef]

9. Misek, S.A.; Appleton, K.M.; Dexheimer, T.S.; Lisabeth, E.M.; Lo, R.S.; Larsen, S.D.; Gallo, K.A.; Neubig, R.R. Rho-mediated signaling promotes BRAF inhibitor resistance in de-differentiated melanoma cells. Oncogene 2020, 39, 1466-1483. [CrossRef] [PubMed]

10. Konieczkowski, D.J.; Johannessen, C.M.; Abudayyeh, O.; Kim, J.W.; Cooper, Z.A.; Piris, A.; Frederick, D.T.; Barzily-Rokni, M.; Straussman, R.; Haq, R.; et al. A melanoma cell state distinction influences sensitivity to MAPK pathway inhibitors. Cancer Discov. 2014, 4, 816-827. [CrossRef] [PubMed]

11. Verfaillie, A.; Imrichova, H.; Atak, Z.K.; Dewaele, M.; Rambow, F.; Hulselmans, G.; Christiaens, V.; Svetlichnyy, D.; Luciani, F.; Van Der Mooter, L.L.; et al. Decoding the regulatory landscape of melanoma reveals TEADS as regulators of the invasive cell state. Nat. Commun. 2015, 6, 6683. [CrossRef] 
12. Kholmanskikh, O.; Van Baren, N.; Brasseur, F.; Ottaviani, S.; Vanacker, J.; Arts, N.; Van Der Bruggen, P.; Coulie, P.; De Plaen, E. Interleukins $1 \alpha$ and $1 \beta$ secreted by some melanoma cell lines strongly reduce expression of MITF-M and melanocyte differentiation antigens. Int. J. Cancer 2010, 127, 1625-1636. [CrossRef]

13. Miskolczi, Z.; Smith, M.P.; Rowling, E.J.; Ferguson, J.; Barriuso, J.; Wellbrock, C. Collagen abundance controls melanoma phenotypes through lineage-specific microenvironment sensing. Oncogene 2018, 37, 3166-3182. [CrossRef]

14. Strub, T.; Kobi, D.; Koludrovic, D.; Davidson, I. Research on Melanoma-A Glimpse into Current Directions and Future Trends; Murph, M., Ed.; IntechOpen: London, UK, 2011.

15. Thurber, A.; Douglas, G.; Sturm, E.; Zabierowski, S.; Smit, D.; Ramakrishnan, S.; Hacker, E.; Leonard, J.; Herlyn, M.; Sturm, R. Inverse expression states of the BRN2 and MITF transcription factors in melanoma spheres and tumour xenografts regulate the NOTCH pathway. Oncogene 2011, 30, 3036-3048. [CrossRef]

16. O'Connell, M.P.; Marchbank, K.; Webster, M.R.; Valiga, A.A.; Kaur, A.; Vultur, A.; Li, L.; Herlyn, M.; Villanueva, J.; Liu, Q.; et al. Hypoxia induces phenotypic plasticity and therapy resistance in melanoma via the tyrosine kinase receptors ROR1 and ROR2. Cancer Discov. 2013, 3, 1378-1393. [CrossRef] [PubMed]

17. Landsberg, J.; Kohlmeyer, J.; Renn, M.; Bald, T.; Rogava, M.; Cron, M.; Fatho, M.; Lennerz, V.; Wölfel, T.; Hölzel, M.; et al. Melanomas resist T-cell therapy through inflammation-induced reversible dedifferentiation. Nature 2012, 490, 412-416. [CrossRef] [PubMed]

18. Mehta, A.; Kim, Y.J.; Robert, L.; Tsoi, J.; Comin-Anduix, B.; Berent-Maoz, B.; Cochran, A.J.; Economou, J.S.; Tumeh, P.C.; Puig-Saus, C.; et al. Immunotherapy resistance by inflammation-induced dedifferentiation. Cancer Discov. 2018, 8, 935-943. [CrossRef] [PubMed]

19. Müller, J.; Krijgsman, O.; Tsoi, J.; Robert, L.; Hugo, W.; Song, C.; Kong, X.; Possik, P.A.; Cornelissen-Steijger, P.D.M.; Foppen, M.H.G.; et al. Low MITF/AXL ratio predicts early resistance to multiple targeted drugs in melanoma. Nat. Commun. 2014, 5, 5712. [CrossRef]

20. Kozar, I.; Margue, C.; Rothengatter, S.; Haan, C.; Kreis, S. Many ways to resistance: How melanoma cells evade targeted therapies. Biochim. Biophys. Acta Rev. Cancer 2019, 1871, 313-322. [CrossRef]

21. Arozarena, I.; Wellbrock, C. Phenotype plasticity as enabler of melanoma progression and therapy resistance. Nat. Rev. Cancer 2019, 19, 377-391. [CrossRef] [PubMed]

22. Moustakas, A.; Heldin, C.H. Non-smad TGF- $\beta$ signals. J. Cell Sci. 2005, 118, 3573-3584. [CrossRef] [PubMed]

23. Moustakas, A.; Heldin, C.-H. Dynamic control of TGF- $\beta$ signaling and its links to the cytoskeleton. FEBS Lett. 2008, 582, 2051-2065. [CrossRef] [PubMed]

24. Kim, J.-G.; Islam, R.; Cho, J.Y.; Jeong, H.; Cap, K.-C.; Park, Y.; Hossain, A.J.; Park, J.-B. Regulation of RhoA GTPase and various transcription factors in the RhoA pathway. J. Cell. Physiol. 2018, 233, 6381-6392. [CrossRef] [PubMed]

25. Lin, C.; Yao, E.; Zhang, K.; Jiang, X.; Croll, S.; Thompson-Peer, K.; Chuang, P.-T. YAP is essential for mechanical force production and epithelial cell proliferation during lung branching morphogenesis. eLife 2017, 6, e21130. [CrossRef]

26. Edwards, D.N.; Ngwa, V.M.; Wang, S.; Shiuan, E.; Brantley-Sieders, D.M.; Kim, L.C.; Reynolds, A.B.; Chen, J. The receptor tyrosine kinase EphA2 promotes glutamine metabolism in tumors by activating the transcriptional coactivators YAP and TAZ. Sci. Signal. 2017, 10, eaan4667. [CrossRef] [PubMed]

27. Srivastava, S.; Pang, K.M.; Iida, M.; Nelson, M.S.; Liu, J.; Nam, A.; Wang, J.; Mambetsariev, I.; Pillai, R.; Mohanty, A.; et al Activation of EPHA2-ROBO1 heterodimer by SLIT2 attenuates non-canonical signaling and proliferation in squamous cell carcinomas. iScience 2020, 23, 101692. [CrossRef] [PubMed]

28. Malik, A.; Kanneganti, T.-D. Function and regulation of IL-1 $\alpha$ in inflammatory diseases and cancer. Immunol. Rev. 2018, 281, 124-137. [CrossRef]

29. Paňková, D.; Jobe, N.; Kratochvílová, M.; Buccione, R.; Brábek, J.; Rösel, D. NG2-mediated Rho activation promotes amoeboid invasiveness of cancer cells. Eur. J. Cell Biol. 2012, 91, 969-977. [CrossRef]

30. Vaškovičová, K.; Szabadosová, E.; Čermák, V.; Gandalovičová, A.; Kasalová, L.; Rösel, D.; Brábek, J. PKC $\alpha$ promotes the mesenchymal to amoeboid transition and increases cancer cell invasiveness. BMC Cancer 2015, 15, 326. [CrossRef]

31. Dovas, A.; Yoneda, A.; Couchman, J.R. PKC- $\alpha$-dependent activation of RhoA by syndecan- 4 during focal adhension formation. J. Cell Sci. 2006, 119, 2837-2846. [CrossRef]

32. Riesenberg, S.; Groetchen, A.; Siddaway, R.; Bald, T.; Reinhardt, J.; Smorra, D.; Kohlmeyer, J.; Renn, M.; Phung, B.; Aymans, P.; et al. MITF and c-Jun antagonism interconnects melanoma dedifferentiation with pro-inflammatory cytokine responsiveness and myeloid cell recruitment. Nat. Commun. 2015, 6, 8755. [CrossRef]

33. Arts, N.; Cané, S.; Hennequart, M.; Lamy, J.; Bommer, G.; Van Den Eynde, B.; De Plaen, E. microRNA-155, Induced by interleukin-11, represses the expression of microphthalmia-associated transcription factor (MITF-M) in melanoma cells. PLoS ONE 2015, 10, e0122517. [CrossRef] [PubMed]

34. Soustek, M.S.; Balsa, E.; Barrow, J.J.; Jedrychowski, M.; Vogel, R.; Gygi, S.P.; Puigserver, P. Inhibition of the ER stress IRE1 $\alpha$ inflammatory pathway protects against cell death in mitochondrial complex I mutant cells. Cell Death Dis. 2018, 9, 658. [CrossRef] [PubMed]

35. Chaudhari, N.; Talwar, P.; Parimisetty, A.; d'Hellencourt, C.L.; Ravanan, P. A molecular web: Endoplasmic reticulum stress, inflammation, and oxidative stress. Front. Cell. Neurosci. 2014, 8, 213. [CrossRef] 
36. Ju, R.J.; Stehbens, S.J.; Haass, N.K. The role of melanoma cell-stroma interaction in cell motility, invasion, and metastasis. Front. Med. 2018, 5, 5. [CrossRef] [PubMed]

37. Paňková, K.; Rösel, D.; Novotný, M.; Brábek, J. The molecular mechanisms of transition between mesenchymal and amoeboid invasiveness in tumor cells. Cell. Mol. Life Sci. 2009, 67, 63-71. [CrossRef] [PubMed]

38. Kosla, J.; Paňková, D.; Plachý, J.; Tolde, O.; Bicanová, K.; Dvořák, M.; Rösel, D.; Brábek, J. Metastasis of aggressive amoeboid sarcoma cells is dependent on Rho/ROCK/MLC signaling. Cell Commun. Signal. 2013, 11, 51. [CrossRef] [PubMed]

39. Micuda, S.; Rösel, D.; Ryska, A.; Brábek, J. ROCK inhibitors as emerging therapeutic candidates for sarcomas. Curr. Cancer Drug Targets 2010, 10, 127-134. [CrossRef]

40. Voller, J.; Zahajská, L.; Plíhalová, L.; Jeřábková, J.; Burget, D.; Pataki, A.C.; Kryštof, V.; Zatloukal, M.; Brábek, J.; Rösel, D.; et al. 6-substituted purines as ROCK inhibitors with anti-metastatic activity. Bioorg. Chem. 2019, 90, 103005. [CrossRef]

41. Cantelli, G.; Orgaz, J.L.; Rodriguez-Hernandez, I.; Karagiannis, P.; Maiques, O.; Matias-Guiu, X.; Nestle, F.O.; Marti, R.M.; Karagiannis, S.N.; Sanz-Moreno, V. TGF- $\beta$-induced transcription sustains amoeboid melanoma migration and dissemination. Curr. Biol. 2015, 25, 2899-2914. [CrossRef]

42. Georgouli, M.; Herraiz, C.; Crosas-Molist, E.; Fanshawe, B.; Maiques, O.; Perdrix, A.; Pandya, P.; Rodriguez-Hernandez, I.; Ilieva, K.M.; Cantelli, G.; et al. Regional activation of myosin II in cancer cells drives tumor progression via a secretory cross-talk with the immune microenvironment. Cell 2019, 176, 757-774.e23. [CrossRef] [PubMed]

43. Merta, L.; Gandalovičová, A.; Čermák, V.; Dibus, M.; Gutschner, T.; Diederichs, S.; Rösel, D.; Brábek, J. Increased level of long non-coding RNA MALAT1 is a common feature of amoeboid invasion. Cancers 2020, 12, 1136. [CrossRef]

44. Sanz-Moreno, V.; Gaggioli, C.; Yeo, M.; Albrengues, J.; Wallberg, F.; Viros, A.; Hooper, S.; Mitter, R.; Féral, C.C.; Cook, M.; et al. ROCK and JAK1 signaling cooperate to control actomyosin contractility in tumor cells and stroma. Cancer Cell 2011, 20, 229-245. [CrossRef]

45. Sanz-Moreno, V.; Gadea, G.; Ahn, J.; Paterson, H.; Marra, P.; Pinner, S.; Sahai, E.; Marshall, C.J. Rac activation and inactivation control plasticity of tumor cell movement. Cell 2008, 135, 510-523. [CrossRef]

46. Karaman, M.W.; Herrgard, S.; Treiber, D.K.; Gallant, P.; Atteridge, C.E.; Campbell, B.T.; Chan, K.W.; Ciceri, P.; Davis, M.I.; Edeen, P.T.; et al. A quantitative analysis of kinase inhibitor selectivity. Nat. Biotechnol. 2008, 26, 127-132. [CrossRef]

47. Bain, J.; Plater, L.; Elliott, M.; Shpiro, N.; Hastie, C.J.; Mclauchlan, H.; Klevernic, I.; Arthur, J.S.C.; Alessi, D.R.; Cohen, P. The selectivity of protein kinase inhibitors: A further update. Biochem. J. 2007, 408, 297-315. [CrossRef]

48. Palušová, V.; Renzová, T.; Verlande, A.; Vaclová, T.; Medková, M.; Cetlová, L.; Sedláčková, M.; Hříbková, H.; Slaninová, I.; Krutá, M.; et al. Dual targeting of BRAF and mTOR signaling in melanoma cells with pyridinyl imidazole compounds. Cancers 2020, 12, 1516. [CrossRef]

49. Yang, C.; Zhu, Z.; Tong, B.C.-K.; Iyaswamy, A.; Xie, W.-J.; Zhu, Y.; Sreenivasmurthy, S.G.; Senthilkumar, K.; Cheung, K.H.; Song, J.-X.; et al. A stress response P38 MAP kinase inhibitor SB202190 promoted TFEB/TFE3-dependent autophagy and lysosomal biogenesis independent of P38. Redox Biol. 2020, 32, 101445. [CrossRef]

50. Čermák, V.; Škarková, A.; Merta, L.; Rösel, D.; Brábek, J. Melanoma Phenotype Switch in 3D Collagen After P38 MAPK Inhibitor Treatment. Available online: https:/ / doi.org/10.6084/m9.figshare.c.5215253 (accessed on 7 March 2021).

51. Hemesath, T.J.; Steingrímsson, E.; McGill, G.; Hansen, M.J.; Vaught, J.; Hodgkinson, C.A.; Arnheiter, H.; Copeland, N.G.; Jenkins, N.A.; Fisher, D.E. Microphthalmia, a critical factor in melanocyte development, defines a discrete transcription factor family. Genes Dev. 1994, 8, 2770-2780. [CrossRef]

52. Martina, J.A.; Puertollano, R. Rag GTPases mediate amino acid-dependent recruitment of TFEB and MITF to lysosomes. J. Cell Biol. 2013, 200, 475-491. [CrossRef]

53. Amae, S.; Fuse, N.; Yasumoto, K.I.; Sato, S.; Yajima, I.; Yamamoto, H.; Udono, T.; Durlu, Y.K.; Tamai, M.; Takahashi, K.; et al. Identification of a novel isoform of microphthalmia-associated transcription factor that is enriched in retinal pigment epithelium. Biochem. Biophys. Res. Commun. 1998, 247, 710-715. [CrossRef]

54. Yasumoto, K.; Takeda, K.; Saito, H.; Watanabe, K.; Takahashi, K.; Shibahara, S. Microphthalmia-associated transcription factor interacts with LEF-1, a mediator of Wnt signaling. EMBO J. 2002, 21, 2703-2714. [CrossRef]

55. Čermák, V.; Gandalovičová, A.; Merta, L.; Harant, K.; Rösel, D.; Brábek, J. High-throughput transcriptomic and proteomic profiling of mesenchymal-amoeboid transition in 3D collagen. Sci. Data 2020, 7, 1-11. [CrossRef]

56. Clark, E.A.; Golub, T.R.; Lander, E.S.; Hynes, R.O. Genomic analysis of metastasis reveals an essential role for RhoC. Nature 2000, 406, 532-535. [CrossRef]

57. Kozlowski, J.M.; Fidler, I.J.; Hanna, N.; Hart, I.R. A human melanoma line heterogeneous with respect to metastatic capacity in athymic nude mice. J. Natl. Cancer Inst. 1984, 72, 913-917. [CrossRef]

58. Martin, M. Cutadapt removes adapter sequences from high-throughput sequencing reads. EMBnet J. 2011, 17, 10-12. [CrossRef]

59. Dobin, A.; Davis, C.A.; Schlesinger, F.; Drenkow, J.; Zaleski, C.; Jha, S.; Batut, P.; Chaisson, M.; Gingeras, T.R. STAR: Ultrafast universal RNA-seq aligner. Bioinformatics 2013, 29, 15-21. [CrossRef]

60. Čermák, V.; Gandalovičová, A.; Merta, L.; Rösel, D.; Brábek, J. RNA-Seq Of Human Melanoma Cell Line A375m2 Treated with SB202190 or BIRB796 against DMSO-Treated Controls. Available online: https://identifiers.org/arrayexpress:E-MTAB-9273 (accessed on 28 November 2020). 
61. Bustin, S.A.; Benes, V.; Garson, J.A.; Hellemans, J.; Huggett, J.; Kubista, M.; Mueller, R.; Nolan, T.; Pfaffl, M.W.; Shipley, G.L.; et al. The MIQE guidelines: Minimum information for publication of quantitative real-time PCR experiments. Clin. Chem. 2009, 55, 611-622. [CrossRef]

62. Vandesompele, J.; De Preter, K.; Pattyn, F.; Poppe, B.; Van Roy, N.; De Paepe, A.; Speleman, F. Accurate normalization of real-time quantitative RT-PCR data by geometric averaging of multiple internal control genes. Genome Biol. 2002, 3, 0034. [CrossRef]

63. Perkins, J.R.; Dawes, J.M.; McMahon, S.B.; Bennett, D.L.H.; Orengo, C.; Kohl, M. ReadqPCR and NormqPCR: R packages for the reading, quality checking and normalisation of RT-QPCR quantification cycle (Cq) data. BMC Genom. 2012, 13, 296. [CrossRef]

64. Benjamini, Y.; Hochberg, Y. Controlling the False Discovery Rate: A Practical and Powerful Approach to Multiple Testing. J. R. Stat. Soc. Ser. B 1995, 57, 289-300. [CrossRef]

65. Čermák, V.; Gandalovičová, A.; Merta, L.; Fučíková, J.; Špíšek, R.; Rösel, D.; Brábek, J. RNA-seq of macrophages of amoeboid or mesenchymal migratory phenotype due to specific structure of environment. Sci. Data 2018, 5, 180198. [CrossRef] [PubMed]

66. Kuleshov, M.V.; Jones, M.R.; Rouillard, A.D.; Fernandez, N.F.; Duan, Q.; Wang, Z.; Koplev, S.; Jenkins, S.L.; Jagodnik, K.M.; Lachmann, A.; et al. Enrichr: A comprehensive gene set enrichment analysis web server 2016 update. Nucleic Acids Res. 2016, 44, W90-W97. [CrossRef]

67. Folberg, R.; Arbieva, Z.; Moses, J.; Hayee, A.; Sandal, T.; Kadkol, S.H.; Lin, A.Y.; Valyi-Nagy, K.; Setty, S.; Leach, L.; et al. Tumor cell plasticity in uveal melanoma: Microenvironment directed dampening of the invasive and metastatic genotype and phenotype accompanies the generation of vasculogenic mimicry patterns. Am. J. Pathol. 2006, 169, 1376-1389. [CrossRef] [PubMed]

68. Molbiotools. Multiple List Comparator. Available online: http:/ / www.molbiotools.com/listcompare.html (accessed on 4 March 2021).

69. Andrews, S. FastQC: A Quality Control Tool for High Throughput Sequence Data. Available online: http://www.bioinformatics. babraham.ac.uk/projects/fastqc/ (accessed on 21 November 2020).

70. Love, M.I.; Huber, W.; Anders, S. Moderated estimation of fold change and dispersion for RNA-seq data with DESeq2. Genome Biol. 2014, 15, 550. [CrossRef] [PubMed]

71. Widmer, D.S.; Cheng, P.F.; Eichhoff, O.M.; Belloni, B.C.; Zipser, M.C.; Schlegel, N.C.; Javelaud, D.; Mauviel, A.; Dummer, R.; Hoek, K.S. Systematic classification of melanoma cells by phenotype-specific gene expression mapping. Pigment. Cell Melanoma Res. 2012, 25, 343-353. [CrossRef]

72. Han, H.; Cho, J.-W.; Lee, S.-Y.; Yun, A.; Kim, H.; Bae, D.; Yang, S.; Kim, C.Y.; Lee, M.; Kim, E.; et al. TRRUST v2: An expanded reference database of human and mouse transcriptional regulatory interactions. Nucleic Acids Res. 2018, 46, D380-D386. [CrossRef]

73. Tirosh, I.; Izar, B.; Prakadan, S.M.; Wadsworth, M.H.; Treacy, D.; Trombetta, J.J.; Rotem, A.; Rodman, C.; Lian, C.; Murphy, G.; et al Dissecting the multicellular ecosystem of metastatic melanoma by single-cell RNA-Seq. Science 2016, 352, 189-196. [CrossRef]

74. Jeffs, A.R.; Glover, A.C.; Slobbe, L.J.; Wang, L.; He, S.; Hazlett, J.A.; Awasthi, A.; Woolley, A.G.; Marshall, E.S.; Joseph, W.R.; et al. A gene expression signature of invasive potential in metastatic melanoma cells. PLoS ONE 2009, 4, e8461. [CrossRef]

75. Rodriguez-Hernandez, I.; Maiques, O.; Kohlhammer, L.; Cantelli, G.; Perdrix-Rosell, A.; Monger, J.; Fanshawe, B.; Bridgeman, V.L.; Karagiannis, S.N.; Penin, R.M.; et al. WNT11-FZD7-DAAM1 signalling supports tumour initiating abilities and melanoma amoeboid invasion. Nat. Commun. 2020, 11, 1-20. [CrossRef]

76. Arozarena, I.; Bischof, H.; Gilby, D.; Belloni, B.; Dummer, R.; Wellbrock, C. In melanoma, beta-catenin is a suppressor of invasion. Oncogene 2011, 30, 4531-4543. [CrossRef] [PubMed]

77. Parri, M.; Taddei, M.L.; Bianchini, F.; Calorini, L.; Chiarugi, P. EphA2 reexpression prompts invasion of melanoma cells shifting from mesenchymal to amoeboid-like motility style. Cancer Res. 2009, 69, 2072-2081. [CrossRef] [PubMed] 